\title{
MODEL PENERAPAN AKUNTANSI SEKTOR PUBLIK UNTUK MENCEGAH FRAUD PADA SEKTOR PUBLIK DI ERA DIGITAL
}

\author{
DIAN KRISTIYANI \\ HAMIDAH \\ Universitas Airlangga, Jl. Airlangga No.4, Airlangga, Kec. Gubeng, Surabaya, Indonesia \\ diankristiyaniunair123@gmail.com
}

\begin{abstract}
This study aims to find and describe the characteristics of fraud that occur in the public sector in the digital era and develop models of application of Public Sector Accounting to prevent fraud that occurs in the public sector in the digital age. The research carried out is a literature review study sourced from articles in accordance with the research topic for further analysis. The results showed that the characteristics of fraud in the public sector that occurred in the digital era include the use of misconceptions regarding the role of digital technology in the implementation of public accounting tasks, the utilization of digital technology to optimize opportunities for fraud, exploiting problems in human error and lack of knowledge in the use of technology. digital, using digital technology products, to carry out fraud. Application of Public Sector Accounting can prevent fraud in the public sector in the digital era if implemented by considering several factors that influence fraud, such as performance accountability, and accompanied by the application of fraud prevention methods which include technical strategies, two paradigm approaches, and preventive strategies.
\end{abstract}

Keywords: Fraud, public sector accounting, digital era, behavioral accounting

Abstrak: Penelitian ini bertujuan untuk menemukan dan mendeskripsikan karakteristik fraud yang terjadi pada sektor publik di era digital dan mengembangkan model penerapan Akuntansi Sektor Publik untuk mencegah fraud yang terjadi pada sektor publik di era digital. Penelitian yang dilakukan merupakan penelitian kajian literatur yang bersumber pada artikel yang sesuai dengan topik penelitian untuk dianalisis lebih lanjut. Hasil penelitian menunjukkan bahwa karakteristik fraud pada sektor publik yang terjadi di era digital antara lain berupa pemanfaatan miskonsepsi mengenai peranan teknologi digital terhadap pelaksanaan tugas akuntan publik, pendayagunaan teknologi digital untuk mengoptimalkan kesempatan untuk melakukan fraud, memanfaatkan permasalahan dalam human error dan kurangnya pengetahuan dalam pemanfaatan teknologi digital, menggunakan produk teknologi digital, untuk melaksanakan fraud. Penerapan Akuntansi Sektor Publik dapat mencegah terjadinya fraud pada sektor publik di era digital jika dilaksanakan dengan mempertimbangkan beberapa faktor yang mempengaruhi fraud, seperti performance accountability, dan melakukan strategi teknis, pendekatan dua paradigma, dan strategi preventif.

Kata kunci: Fraud, akuntansi sektor publik, era digital, akuntansi keperilakuan 


\section{PENDAHULUAN}

Teknologi yang terus mengalami perkembangan membawa dampak yang signifikan terhadap berbagai proses dalam kehidupan manusia. Dampak tersebut dapat berupa dampak positif, yang mendorong peningkatan efektivitas dan efisiensi kegiatan manusia, atau justru dampak yang bersifat negatif, yaitu dalam bentuk penyalahgunaan teknologi untuk mendapatkan keuntungan pribadi dan menciptakan kerugian pada pihak lain. Dua sisi dampak teknologi ini menuntut adanya perubahan paradigma terhadap teknologi yang didasarkan pada pertimbangan bijak demi memastikan bahwa kemajuan teknologi benar-benar menjadi instrumen yang mempermudah manusia dalam melaksanakan aktivitasnya.

Dampak yang diharapkan dari kemajuan teknologi terhadap akuntansi sektor publik adalah berupa semakin mudah dan cepatnya pelaksanaan berbagai proses akuntansi, serta semakin akuratnya informasi yang dihasilkan dari proses tersebut. Namun demikian, hal ini hanya dapat dicapai jika para pihak yang terlibat dalam proses akuntansi memiliki kapabilitas untuk mendayagunakan produk teknologi dengan optimal dan dengan tujuan positif, yaitu untuk meningkatkan pelayanan kepada publik (Kementrian Riset dan Teknologi Republik Indonesia, 2018). Kapabilitas dan tujuan positif dari penggunaan teknologi dalam proses akuntansi akan mengarah pada efisiensi dan efektivitas yang semakin tinggi. Sebaliknya, kapabilitas yang disandingkan dengan tujuan yang negatif, yaitu untuk mendapatkan manfaat bagi diri sendiri, akan menyebabkan terjadinya fraud.

Menurut Omar, Nawawi, \& Salin (2016), fraud adalah suatu risiko usaha yang dapat muncul di setiap entitas bisnis, baik pada lembaga negara maupun perusahaan milik swasta. Perusahaan yang berukuran besar maupun kecil tidak dapat terlepas dari potensi terjadinya fraud di dalamnya, sehingga dapat dikatakan bahwa tidak ada perusahaan yang immune dari penyakit yang bernama fraud. Menurut teori fraud triangle, fraud dapat terjadi karena adanya tiga faktor utama yang menyebabkannya, yaitu tekanan, kesempatan, dan rasionalisasi. Selanjutnya terdapat juga teori fraud diamond yang merupakan pengembangan dari fraud triangle dengan satu faktor penyebab tambahan, yaitu kapabilitas (Eyo Bassey, 2018). Inti dari teori tersebut menyatakan bahwa seseorang yang melakukan fraud mendapatkan dorongan dari dua kategori faktor, yaitu faktor internal yang berupa kapabilitas dan rasionalisasi, dan faktor eksternal yang meliputi tekanan dan kesempatan.

Apabila dikaitkan dengan kemajuan teknologi yang telah sampai pada tingkat digital seperti saat ini, maka kapabilitas yang dimiliki individu dalam mendayagunakan produk teknologi digital dapat menjadi pendorong kuat untuk melaksanakan fraud. Terlebih lagi, penerapan teknologi digital yang masih belum merata karena pengetahuan dan kemampuan pengoperasionalan teknologi tersebut yang masih belum dimiliki oleh seluruh entitas usaha, termasuk sektor publik, menghadirkan kesempatan besar untuk melakukan fraud.

Fraud secara garis besar dapat digolongkan ke dalam tiga jenis tindakan, yaitu penyalahgunaan aset, pernyataan palsu dalam laporan keuangan, dan korupsi (Sihombing, Erlina, Rujiman, \& Muda, 2019). Menurut hasil survei yang dilakukan oleh Association of Certified Fraud Examiners Indonesia Chapter (ACFE-IC), korupsi merupakan jenis fraud yang paling banyak terjadi di Indonesia, disusul oleh penyalahgunaan aset, dan terakhir adalah kecurangan laporan keuangan. 


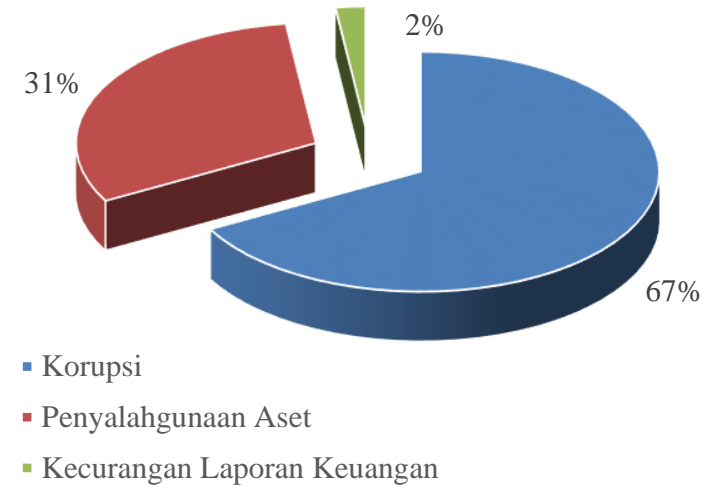

Gambar 1 Frekuensi Fraud di Indonesia tahun 2016

Sumber: Association of Certified Fraud Examiners (ACFE) Indonesia Chapter (2017)

Berdasarkan data tersebut, ACFE IC juga menggambarkan estimasi kerugian yang diakibatkan oleh masing-masing jenis fraud di atas. Sesuai dengan frekuensinya, korupsi menjadi jenis fraud yang paling merugikan, disusul oleh penyalagunaan aset, dan terakhir kecurangan laporan keuangan.

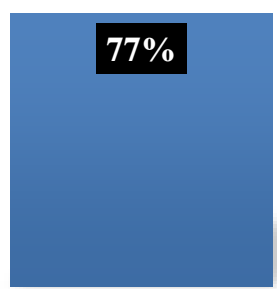

Korupsi

\section{$19 \%$}

Penyalahgunaan Aset
$4 \%$

Kecurangan Laporan

Keuangan

Gambar 2 Fraud Paling Merugikan di Indoensia tahun 2016

Sumber: Association of Certified Fraud Examiners (ACFE) Indonesia Chapter (2017)

Korupsi selain menjadi jenis fraud yang paling banyak terjadi, juga memiliki jumlah kejadian yang semakin meningkat dari tahun ke tahun. Hal ini sesuai dengan data rekapitulasi tindak pidana korupsi yang dihimpun oleh Anti Corruption Clearing House KPK di bawah ini: 


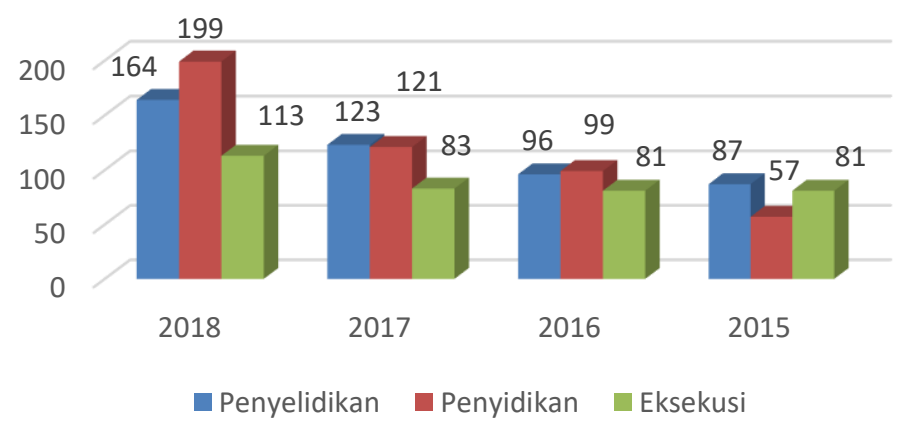

Gambar 3 Tren Peningkatan Jumlah Korupsi

Sumber: Komisi Pemberantasan Korupsi Indonesia (2018)

Peningkatan jumlah fraud terutama kasus korupsi sebagaimana data di atas kemungkinan besar memiliki keterkaitan dengan adanya teknologi digital yang memberikan kapabilitas dan kesempatan lebih besar bagi para pelaku fraud. Namun demikian, hal tersebut masih belum pernah dikaji oleh peneliti terdahulu. Padahal, pemahaman mengenai karakteristik fraud yang terjadi pada sektor publik di era digital akan sangat membantu dalam perumusan strategi untuk mengidentifikasi indikasi terjadinya fraud serta strategi untuk mencegah fraud di masa mendatang, serta dapat memudahkan dalam penerapan Akuntansi Sektor Publik guna mencapai tujuan untuk menghasilkan informasi keuangan yang akurat.

Akuntansi sektor publik merupakan mekanisme akuntansi swasta yang diberlakukan dalam praktik-praktik organisasi publik. Akuntansi sektor publik memiliki ruang lingkup lembaga tinggi negara dan departemen yang berada di bawahnya, seperti pemerintah daerah, yayasan, partai politik, maupun organisasi nirlaba lainnya (Halim, 2016). Dengan demikian, praktikpraktik akuntansi sektor publik adalah sama dengan praktik akuntansi pada umumnya, hanya saja terdapat batasan pada pemangku kepentingannya yang merupakan pihak yang berasal dari pemerintahan dan masyarakat luas.
Pendekatan teori yang digunakan untuk menjelaskan fraud dalam penelitian ini adalah akuntansi keperilakuan, yaitu sebuah teori yang menjelaskan hubungan antara sistem informasi akuntansi dengan perilaku manusia. Sebagaimana dijelaskan oleh Kutluk (2017), bahwa akuntansi keperilakuan mempelajari perilaku manusia, baik yang berprofesi sebagai akuntan atau selain akuntan, berkaitan dengan pengaruhnya terhadap sistem akuntansi dan faktor pembentuk perilaku tersebut yang berasal dari sistem akuntansi. Pelaksana akuntansi keperilakuan, yang merupakan akuntan keperilakuan, memiliki tugas untuk menganalisis perilaku manusia dan persepsi manusia terhadap pekerjaannya, tugasnya, perusahaannya, maupun rekan kerjanya, untuk disampaikan kepada pengguna informasi keperilakuan sebagai dasar pengambilan keputusan dan perumusan prediksi mengenai perilaku manusia di masa depan, serta untuk menentukan strategi yang paling tepat untuk mengubah atau mengarahkan perilaku manusia sesuai dengan tujuan yang ingin dicapai.

Hasil analisis keperilakuan mencakup bagaimana manusia berperilaku dan faktor yang mendasari terbentuknya perilaku tersebut, serta rekomendasi untuk memperbaiki perilaku yang dianggap disfungsional (Supriyono, 2018). Lebih lanjut dijelaskan oleh Supriyono (2018), 
keterhubungan yang dikaji tersebut sifatnya timbal balik, dimana perilaku manusia dapat memberikan pengaruh terhadap informasi akuntansi beserta keputusan bisnis yang diambil. Sebaliknya, informasi akuntansi juga dapat mempengaruhi perilaku manusia serta keputusan bisnis yang diambil.

Berdasarkan penjelasan tersebut, maka penelitian ini akan mengkaji mengenai model penerapan akuntansi sektor publik untuk mencegah terjadinya fraud pada sektor publik di era digital. Kajian didasarkan pada teori akuntansi keperilakuan untuk menemukan keterkaitan antara perilaku negatif berupa fraud terhadap penerapan akuntansi sektor publik pada sektor publik.

\section{Akuntansi Keperilakuan}

Akuntansi keperilakuan mempelajari perilaku manusia, baik yang berprofesi sebagai akuntan atau selain akuntan, berkaitan dengan pengaruhnya terhadap sistem akuntansi dan faktor pembentuk perilaku tersebut yang berasal dari sistem akuntansi (Akay, Poputra, \& Kalalo, 2016). Berdasarkan pengertian tersebut, maka pelaksana akuntansi keperilakuan, yaitu akuntan keperilakuan, memiliki tugas untuk menganalisis perilaku manusia dan persepsi manusia terhadap pekerjaannya, tugasnya, perusahaannya, maupun rekan kerjanya, untuk disampaikan kepada pengguna informasi keperilakuan sebagai dasar pengambilan keputusan dan perumusan prediksi mengenai perilaku manusia di masa depan, serta untuk menentukan strategi yang paling tepat untuk mengubah atau mengarahkan perilaku manusia sesuai dengan tujuan yang ingin dicapai. Hasil analisis keperilakuan mencakup bagaimana manusia berperilaku dan faktor yang mendasari terbentuknya perilaku tersebut, serta rekomendasi untuk memperbaiki perilaku yang dianggap disfungsional (Supriyono 2018).
Menurut Supriyono (2018), tujuan dari akuntansi keperilakuan antara lain:

1. Menganalisis faktor yang menjelaskan mengenai perilaku manusia yang relevan dengan sistem akuntansi.

2. Merumuskan dan menyampaikan informasi mengenai faktor keperilakuan tersebut kepada pihak pengambil keputusan.

3. Melengkapi informasi yang relevan dengan aspek keperilakuan manusia yang dibutuhkan oleh pengambil keputusan dan dituangkan dalam laporan keuangan.

Adapun lingkup dari Akuntansi Keperilakuan adalah (Supriyono 2018):

1. Pengaruh dari perilaku manusia terhadap desain, penyusunan, dan penggunaan sistem informasi, dimana akuntansi keperilakuan menggambarkan keterkaitan antara pandangan nilai dan sikap dari manajemen suatu perusahaan dalam mengendalikan proses akuntansi dengan fungsi dari setiap elemen dalam perusahaan.

2. Pengaruh dari sistem akuntansi terhadap perilaku manusia, dimana akuntansi keperilakuan mengkaji pengaruh dari sistem akuntansi terhadap motivasi, produktivitas, proses pengambilan keputusan, kepuasan kerja, dan kerja sama yang terjalin antar anggota organisasi.

3. Memprediksi perilaku dan merumuskan strategi untuk mengubah perilaku manusia, dimana akuntansi keperilakuan menganalisis peran dari sistem akuntansi terhadap perubahan perilaku manusia.

\section{Fraud}

Secara harfiah, fraud dapat diartikan sebagai penipuan; kecurangan; atau penggelapan (Said, Alam, Karim, \& Johari 
2018). Fraud merupakan suatu tindakan yang dilakukan dengan penuh kesadaran, bukan karena kelalaian atau ketidak-tahuan, untuk mendapatkan manfaat finansial dengan cara berbuat curang (Peprah 2018, Zanaria 2017). Fraud sebagai tindakan aktif yang dilakukan dengan tujuan untuk menipu pihak lain, sehingga pihak yang tertipu tersebut mengalami kerugian dan pihak yang menipu mendapatkan keuntungan (Hantono 2018).

Fraud dapat digolongkan menjadi tiga jenis perbuatan, yaitu (Antarwiyati \& Purnomo 2017, Sihombing, Erlina, Rujiman, \& Muda 2019):

1. Penyalahgunaan aset, merupakan bentuk fraud yang paling mudah dideteksi karena dilakukan dalam bentuk penyalahgunaan atau pencurian aset, sehingga dapat dihitung atau diukur kerugian yang diderita akibat tindakan fraud tersebut.

2. Pernyataan palsu, merupakan fraud yang dilakukan dalam bentuk rekayasa keuangan dalam penyajian laporan keuangan perusahaan untuk menutupi kondisi keuangan perusahaan yang sebenarnya.

3. Korupsi, merupakan jenis fraud yang sulit untuk dideteksi karena dilaksanakan melalui kerjasama dengan pihak-pihak lain dalam suatu jaringan yang terorganisir dan memiliki cara kerja sistematis. Jenis fraud ini umumnya banyak terjadi di negara-negara berkembang dengan penegakan hukum yang masih lemah dan banyaknya pihak yang kurang menyadari pentingnya tata kelola perusahaan yang baik.

Menurut teori Fraud Triangle yang dikembangkan oleh Donald R. Cressey, fraud dapat terjadi karena disebabkan oleh tiga faktor utama, yaitu adanya tekanan (pressure), kesempatan (opportunity), dan rasionalisasi (rationalization) (Abri, Arumugam, \& Balasingam 2019, Aksa 2018).

1. Tekanan (Pressure)

Seseorang dapat melakukan fraud karena adanya tekanan-tekanan yang diterimanya. Tekanan tersebut dapat dibagi menjadi beberapa jenis, yaitu tekanan finansial, tekanan akan kebiasaan buruk, tekanan pekerjaan, dan tekanan lainnya.

2. Kesempatan (Opportunity)

Kesempatan adalah faktor eksternal yang menyebabkan seseorang terdorong untuk melakukan fraud. Faktor ini umumnya muncul ketika terdapat mekanisme pengendalian yang lemah, seperti kurangnya pengawasan atau audit, sehingga membuat seseorang melihat adanya celah dan memanfaatkannya untuk mendapatkan keuntungan pribadi.

3. Rasionalisasi (Rationalization)

Faktor ketiga ini berasal dari dalam diri seseorang berupa pemikiran yang menganggap bahwa tindakan fraud yang dilakukan adalah hal yang wajar dan dapat diterima secara moral.

Selain teori fraud triangle, terdapat juga teori fraud diamond yang memiliki satu faktor tambahan selain tiga faktor yang disebutkan dalam fraud triangle, yaitu faktor kapasitas (capacity). Menurut Ruankaew (2016), kapasitas merujuk pada posisi atau fungsi seseorang dalam suatu perusahaan yang dapat memberinya kemampuan untuk menciptakan atau mengeksploitasi peluang fraud yang tidak tersedia bagi orang lain. Berdasarkan hal tersebut, maka dapat diketahui bahwa untuk dapat melakukan fraud, maka seseorang perlu memiliki kapasitas, berupa sifat dan kemampuan yang diperlukan untuk mengenali peluang penipuan dan dapat memanfaatkannya untuk mendapatkan keuntungan bagi diri sendiri 
(Sujeewa, Yajid, Azam, \& Dharmaratne 2018). Sifat-sifat dan kapasitas yang dimiliki individu untuk dapat melakukan penipuan antara lain:

1. Posisi atau fungsi otoritatif dalam organisasi; misalnya, CEO yang memiliki kemampuan untuk mempengaruhi dan melaksanakan fraud secara terus menerus.

2. Memiliki kecerdasan untuk mengeksploitasi kelemahan sistem akuntansi dan pengendalian internal, serta memahami bagaimana sistem tersebut bekerja untuk kemudian memanfaatkannya untuk mendapatkan keuntungan.

3. Ego dan keyakinan bahwa perilaku fraud yang dilakukan tidak akan terdeteksi. Keberhasilan atas fraud yang dilakukan akan semakin meningkatkan kepercayaan diri untuk kembali melakukan fraud untuk mendapatkan keuntungan yang semakin besar.

4. Kemampuan untuk secara efektif mengatasi stres karena risiko tertangkap dan mengelola fraud dalam jangka waktu yang lama.

\section{Laporan Keuangan}

Menurut Ikatan Akuntan Indonesia (2016), laporan keuangan adalah bagian dari pelaporan keuangan yang isinya terdiri dari laporan laba rugi, neraca, laporan perubahan kedudukan keuangan, laporan dan catatan lain, dan isi penjelas atas konten laporan keuangan. laporan keuangan adalah suatu laporan yang menunjukkan data keuangan perusahaan, yang diringkas dalam bentuk laporan laba rugi, neraca, dan laporan lain, yang dijadikan sebagai sumber informasi penting bagi pengambil keputusan dan pihakpihak terkait yang memiliki kepentingan.

Menurut Septarini \& Papilaya (2016), laporan keuangan merupakan sumber informasi keuangan penting yang dibutuhkan oleh berbagai pihak yang memiliki kepentingan untuk digunakan sebagai acuan dalam pengambilan keputusan strategis. Oleh karena itu, informasi yang dimuat dalam laporan keuangan harus memiliki kualitas yang baik sesuai dengan karakteristik yang ditetapkan oleh pemerintah. Laporan keuangan disusun dengan tujuan untuk memberikan informasi mengenai posisi keuangan, kinerja keuangan, dan arus kas entitas yang bermanfaat bagi sebagian besar kalangan pengguna laporan keuangan dalam pembuatan keputusan ekonomi serta menunjukkan pertanggungjawaban manajemen atas penggunaan sumber daya yang dipercayakan kepada manajemen (Wahyuni \& Budiwitjaksono 2017). Laporan keuangan mengungkapkan kondisi keuangan perusahaan dalam tiga cara, yaitu (Enyi 2019):

1. Melalui neraca yang melaporkan aset, kewajiban, dan ekuitas pemilik perusahaan.

2. Melalui laporan laba rugi yang menjelaskan mengenai keuntungan dan kerugian perusahaan

3. Melalui laporan arus kas yang menyajikan informasi mengenai sumber kas dan penggunaannya.

\section{METODE}

Penelitian ini berjenis deskriptif dengan pendekatan kualitatif. Menurut Creswell (2014), penelitian deskriptif kualitatif adalah penelitian yang bertujuan untuk melakukan eksplorasi atas topik yang diteliti hingga bisa diperoleh penjelasan rinci dan lengkap. Melalui pendekatan tersebut, peneliti berharap dapat memperoleh informasi yang mampu digunakan untuk mendeskripsikan variabel, gejala, atau keadaan yang menjadi fokus penelitian.

Data penelitian berupa data sekunder yang dikumpulkan melalui studi kepustakaan, yaitu dengan mengumpulkan teori, data 
penelitian atau temuan pada penelitian sebelumnya dengan berbagai sumber yang berkaitan dengan topik penelitian yang akan dikaji. Data yang telah dikumpulkan selanjutnya dianalisis menggunakan metode analisis kualitatif dengan 3 tahapan analisis sebagai berikut (Bungin 2017):

1. Reduksi data

Peneliti menelaah data untuk mengambil data-data yang relevan dan mengesampingkan data yang tidak sesuai dengan penelitian ini.

2. Penyajian Data

Setelah data yang didapat direduksi, selanjutnya data tersebut disajikan dalam bentuk uraian, bagan, hubungan antara kategori, flowchart dan sejenisnya, sehingga memudahkan untuk dilakukan analisis dan interprestasi.

3. Penarikan Kesimpulan

Kesimpulan dalam penelitian kualitatif merupakan temuan yang didapatkan dari analisis terhadap data untuk menjawab permasalahan penelitian. Analisis dilakukan secara induktif dengan mengkedepankan pemikiran dan pemahaman peneliti yang mengacu pada teori yang relevan.

\section{HASIL PENELITIAN}

Era digital menghadirkan paradigma baru dalam dunia akuntansi, bahwa perkembangan teknologi dengan segala produknya dianggap mampu menandingi peran penting akuntan dalam melaksanakan beragam aktivitas akuntansi yang penting bagi perusahaan. Pencatatan keuangan hingga analisis terhadap data keuangan sebagian telah dipercayakan kepada aplikasi dan perangkat lunak komputer daripada mengandalkan kecermatan dan ketelitian seorang akuntan dengan alasan efisiensi dan efektivitas yang jauh lebih unggul. Jika dipandang dari satu sisi saja, maka hal ini merupakan dampak positif teknologi dalam meringankan tugas akuntan, sehingga para akuntan dapat berkosentrasi untuk menjalankan tugas lainnya yang masih belum bisa digantikan oleh komputer (Rini 2019). Namun dari sudut pandang lain hal ini justru menghadirkan tantangan dan ancaman baru yang cukup laten, yaitu kemungkinan terjadinya fraud dengan memanfaatkan teknologi digital dan dengan menjadikan alasan kebutuhan atas efektivitas dan efisiensi sebagai dasar untuk menutupi jejak fraud yang dilakukan serta menggiring opini terhadap keharusan penggunaan teknologi digital yang memungkinkan fraud tersebut menjadi sulit terdeteksi dan berlangsung dalam jangka waktu yang lama.

Tantangan dan ancaman pertama yang sifatnya sangat mendasar adalah pada pola pikir manusia itu sendiri yang menganggap bahwa mesin dan teknologi, dalam hal ini teknologi informasi yang menciptakan ranah digital, dapat menjadi pengganti manusia, khususnya profesi akuntan, dalam melaksanakan fungsi akuntansi (Cahyadi 2019). Padahal, teknologi diciptakan untuk membantu manusia melaksanakan perannya dengna lebih efektif dan efisien, sehingga sampai kapanpun selalu terdapat kesempatan bagi sumber daya manusia untuk berperan dalam berbagai proses penting di seluruh bidang kehidupan (Kruskopf et al. 2019). Namun demikian, hal yang perlu dicermati adalah terkait dengan perlunya manusia untuk juga ikut mengembangkan kapasitas dirinya untuk selalu menjadi lebih baik melalui adaptasi terhadap perkembangan teknologi di sekitarnya. Dalam artian, manusia harus secara aktif mampu menjadikan teknologi sebagai instrumen pengembangan diri dan karirnya dengan cara terus belajar 
(Putritama, 2019). Dengan demikian, cara pandang yang positif terhadap kehadiran teknologi digital sangat penting untuk menempatkan teknologi tersebut sebagai ancaman ataukah sebagai tantangan yang dapat dimanfaatkan untuk pengembangan kapasitas diri.

Permasalahan yang mengemuka dari adanya miskonsepsi tentang peranan teknologi digital adalah pada adanya kesempatan untuk memanfaatkan hal tersebut demi mendapatkan keuntungan pribadi dengan cara menipu pihak yang tidak memiliki pengetahuan memadai mengenai pemanfaatan teknologi digital dalam menunjang proses akuntansi. Hal ini sesuai dengan konsep fraud triangle dan fraud diamond mengenai adanya kesempatan (opportunity) dan kapasitas (capacity) untuk melakukan fraud dengan memanfaatkan perkembangan teknologi digital dan tidak meratanya pengetahuan dan kemampuan untuk menggunakan teknologi tersebut pada sebagian perusahaan (Ruankaew 2016).

Kehadiran teknologi digital, terutama dengan produknya berupa big data dan cloud computing, maka terdapat kecenderungan besar bahwa perusahaan yang menerapkan teknologi tersebut akan merubah metode pengukuran asetnya dari yang semula dilakukan secara konvensional berubah dengan memanfaatkan teknologi digital untuk mengukur asetnya, sehingga seluruh pekerjaan menjadi paperless dan sangat tergantung pada peran aplikasi dan penyimpanan digital (Kementrian Riset dan Teknologi Republik Indonesia, 2018). Aplikasi teknologi digital tersebut memang menawarkan efisiensi dan efektivitas yang jauh lebih tinggi, namun juga diiringi oleh terciptanya potensi terjadinya fraud karena seluruh informasi aset ditentukan oleh proses input data. Sedikit saja terdapat kesalahan dalam input data, maka akan berdampak pada seluruh informasi yang dihasilkan oleh aplikasi. Dalam hal ini, kesalahan tersebut dapat disebabkan karena faktor kelalaian, atau kurangnya kemampuan dalam mengoperasionalkan teknologi, atau karena kesengajaan (fraud).

Produk teknologi digital yang dinilai memudahkan terjadinya fraud salah satunya adalah cryptocurrency, yaitu mata uang digital yang diterapkan menggunakan teknologi kriptografi. Cryptocurrency memiliki empat ciri utama, yaitu sifatnya yang tersedesentralisasi, bersifat anonim, tidak bisa dimanipulasi, dan tidak terdapat inflasi dalam peredarannya (Pertiwi, 2018).

Cryptocurrency

memang

menawarkan beragam kelebihan dibandingkan mata uang fisik. Namun demikian, terdapat potensi besar penggunaannya untuk tujuan fraud, seperti untuk pencucian uang, atau untuk melakukan penipuan dengan cara menawarkan Initial Coin Offering (ICO) palsu dan kemudian dilakukan penggelapan dana investor yang telah membeli ICO tersebut. Fraud menggunakan instrumen cryptocurrency tersebut sangat sulit untuk dilacak karena penggunanya yang dapat menggunakan akun dengan nama samaran, sehingga dapat meloloskan diri dari pelaksanaan audit (Hadi 2018)

Potensi fraud dengan memanfaatkan teknologi digital telah disadari oleh Asosiasi Pemeriksa Fraud Tersertifikasi (Association of Certified Fraud Examiners/ ACFE Indonesia Chapter atau ACFE IC), sehingga mendorong pelaksanaan National Anti Fraud Conference (NAFC) pada 2018 dengan mengangkat tema fraud dalam kategori cryptocurrency investigation sebagai salah satu bahasan pokok dalam konferensi tersebut (CNBC Editorial 2018). Lebih lanjut, ACFE IC juga menyebutkan beberapa model fraud yang pelaksanaannya semakin mudah dengan pemanfaatan teknologi digital (Association of Certified Fraud Examiners (ACFE) Indonesia Chapter, 2018), yang pertama adalah hacking, yaitu dengan 
mencuri akses terhadap data keuangan maupun data penting lainnya oleh para hacker, yang selanjutnya digunakan untuk mendapatkan keuntungan pribadi. Berikutnya adalah malware, yaitu dengan menggunakan virus untuk merusak sistem akuntansi dalam perusahaan. Kemudian social engineering, yaitu memanfaatkan teknologi digital untuk menggali informasi rahasia mengenai keuangan perusahaan. Adapula berupa previlege missuse, yaitu berupa penyalahgunaan akses yang diberikan terhadap informasi penting milik perusahaan, dan phsycial intrusion, yaitu mengakses data perusahaan dengan tanpa izin dan tanpa memiliki kewenangan untuk akses tersebut.

Berkaitan dengan penerapan akuntansi sektor publik untuk mencegah fraud merujuk pada pelaksanaan tujuh elemennya yang mencakup perencanaan publik, penganggaran publik, realisasi anggaran publik, pengadaan barang dan jasa publik, pelaporan keuangan publik, audit sektor publik, dan pertanggung jawaban publik (Bastian, 2015). Pelaksanaan ketujuh elemen tersebut tidak dapat terlepas dari risiko fraud, sebagaimana penjelasan Free (2015) mengenai fraud triangle, bahwa fraud dapat terjadi karena adanya tiga faktor penyebab, yaitu kesempatan, tekanan, dan rasionalisasi. Ditambah lagi dengan kehadiran teknologi digital yang seolah memberikan kesempatan lebih besar serta menambahkan faktor kapasitas (capacity) sebagaimana disebutkan dalam teori fraud diamond (Ruankaew, 2016; Sujeewa et al., 2018). Kapasitas yang dimaksud dalam hal ini adalah adanya kemampuan untuk melakukan fraud dengan memanfaatkan beragam produk teknologi digital.

Fraud pada dasarnya dapat digolongkan menjadi tiga jenis, yaitu dalam bentuk penyalahgunaan aset, pernyataan palsu dalam laporan keuangan, dan korupsi (Sihombing, Erlina, Rujiman, \& Muda, 2019).
Namun sesuai dengan penjelasan dari ACFE IC, maka kehadiran teknologi digital dengan beragam produknya berpotensi untuk menyebabkan terjadinya pengembangan pada metode melakukan fraud pada ketiga jenis fraud tersebut (Association of Certified Fraud Examiners (ACFE) Indonesia Chapter, 2018). Oleh karena itu, sesuai dengan konsepsi perlunya pengembangan kapasitas keilmuan Akuntansi Sektor Publik untuk mengimbangi perkembangan teknologi digital, maka diperlukan juga perumusan model implementasi Akuntansi Sektor Publik yang dapat digunakan untuk mencegah fraud di era digital.

ACFE IC mengemukakan strategi dasar untuk mengatasi terjadinya fraud yang dapat diterapkan oleh sektor publik khususnya maupun sektor usaha lainnya. Strategi tersebut berfokus pada upaya untuk mencegah kehilangan data (Association of Certified Fraud Examiners (ACFE) Indonesia Chapter, 2018). Bentuk strategi yang dapat dilakukan adalah menggunakan jasa privacy officer yang memahami teknologi dan hukum, memiliki program kerja, mampu menetapkan kebijakan keamanan data, berikut teknologi dan instrumen yang dibutuhkan untuk menjaga data perusahaan tetap aman, memahamkan pentingnya kerahasiaan data pelanggan dan data perusahaan, mengelola konektivitas data dengan internet untuk memastikan kebermanfaatan internet of things (IOT) dan mencegah terjadinya penggalian data perusahaan dari pihak eksternal, menentukan tingkat kerahasiaan data perusahaan beserta peringkat wewenang untuk akses data, menetapkan jadwal pelaporan dan memprioritaskan ketepatan waktu pelaporan, dan melaksanakan pemantauan dan pengendalian data secara real time.

Fraud diyakini terjadi karena adanya kesempatan (opportunity) untuk melakukannya. Oleh karena itu, hal penting 
yang dapat dilakukan untuk mencegah terjadinya fraud adalah dengan menghilangkan kesempatan tersebut dengan cara meningkatkan penerapan sistem pengendalian internal, memanfaatkan jasa internal maupun external auditing, melakukan fraud examination, serta memberlakukan forensic accounting, baik secara manual maupun dalam bentuk digital (digital forensic accounting) (Kementrian Riset dan Teknologi Republik Indonesia, 2019).

Fraud adalah tindakan yang dapat dilakukan secara individual maupun kolektif, dan keberadaannya dapat menjadi sebuah wabah atau penyakit mematikan yang menular dalam suatu perusahaan. Oleh karena itu, selain harus menghilangkan kesempatan yang memungkinkan seseorang melakukan fraud, maka upaya kedua yang harus dilakukan adalah dengan menciptakan kultur anti fraud atau kultur kejujuran dalam perusahaan (Kementrian Riset dan Teknologi Republik Indonesia, 2019). Sebagaimana dijelaskan dalam teori Akuntansi Keperilakuan, bahwa perilaku manusia memiliki keterkaitan erat dengan sistem akuntansi, dimana perubahan yang terjadi pada satu sisi akan menjadi faktor pemicu perubahan pada sisi lainnya (Supriyono, 2018). Oleh karena itu, jika perusahaan dapat menciptakan kultur anti fraud hingga mampu mengubah perilaku setiap anggota perusahaan, maka perubahan ini dalam jangka panjang akan dapat menjadi penghalang terjadinya fraud. Cara yang dilakukan adalah dengan menanamkan nilai kejujuran dan menjelaskan dampak negatif fraud terhadap setiap bagian dari perusahaan. Penjelasan tersebut disampaikan kepada pihak dengan jabatan paling tinggi dalam perusahaan hingga ke staf pada tingkat paling bawah oleh akuntan atau oleh staf privacy officer yang khusus menganalisis masalah fraud dalam perusahaan (McMahon, Pence, Bressler, \& Bressler, 2016).

Muhtar, Sutaryo, \& Sriyanto (2018) mengkaji mengenai fraud dalam bentuk korupsi yang terjadi di lembaga publik di Indonesia dengan mengacu pada teori fraud triangle. Hasil penelitiannya menyatakan bahwa korupsi dipengaruhi secara signifikan dan negatif oleh performance accountability, artinya performance accountability yang semakin baik ditunjukkan oleh lembaga pemerintah akan menjadi salah satu pendorong menurunnya fraud yang terjadi di sektor publik tersebut. Performance accountability yang baik akan menyebabkan menurunnya tekanan (pressure) yang diterima sektor publik dari masyarakat dan seluruh stakeholder, sehingga hal ini akan menyebabkan niat untuk melakukan fraud pada setiap anggota sektor publik menjadi menurun.

Terjadinya fraud di era digital semakin sulit untuk diketahui karena adanya instrumen-instrumen baru yang dapat digunakan untuk melaksanakan tindakan tersebut. Ketika dampak negatif berupa kerugian dalam skala besar telah dirasakan, baik dalam bentuk kerugian finansial maupun kerugian dalam aspek lain, maka saat itu perusahaan baru mengetahui adanya fraud. Oleh karena itu, upaya untuk mencegah terjadinya fraud selalu mengutamakan pada metode deteksi yang sifatnya preventif.

Seiring dengan perkembangan teknologi digital, maka metode deteksi fraud juga harus terus dikembangkan agar dapat diterapkan secara efektif dan dapat mendeteksi indikasi fraud yang memanfaatkan teknologi digital. Menurut (Donning, Erikkson, Martikainen, \& Lehner, 2019), pengembangan sistem deteksi fraud bukan merupakan hal yang mudah untuk dilakukan karena melibatkan teknologi baru dan membutuhkan dukungan finansial dari perusahaan yang secara khusus mengalokasikannya untuk keperluan 
memerangi fraud. Namun demikian, penerapan sistem tersebut akan dapat membantu perusahaan dalam memonitor, menganalisis, mempelajari, dan melakukan berbagai upaya cerdas untuk mendeteksi dan melawan fraud. Sistem deteksi fraud yang melaksanakan aktivitasnya dengan menggunakan tiga metode utama, yaitu machine learning algorithms, data mining, dan meta-learning dapat memiliki kecerdasan yang terus berkembang seiring dengan proses yang dilaluinya. Sistem tersebut mampu menyimpan informasi mengenai metode dan karakteristik fraud yang telah diketahui dan menganalisisnya untuk menghasilkan indikator terjadinya fraud, yang selanjutnya digunakan untuk mendeteksi kecenderungan terjadinya fraud.

Secara keseluruhan, model penerapan akuntansi sektor publik dalam mencegah fraud yang terjadi pada Sektor Publik di era digital dapat digambarkan sebagai berikut:

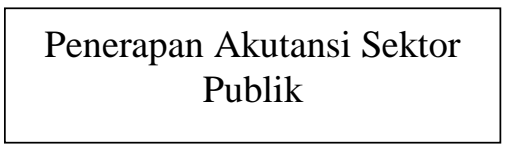

1. Perencanaan Publik

2. Penganggaran Publik

3. Realisasi Anggaran Publik

4. Pengadaan Barang dan Jasa Publik

5. Pelaporan Keuangan Publik

6. Audit Sektor Publik

7. Pertanggung Jawaban Publik

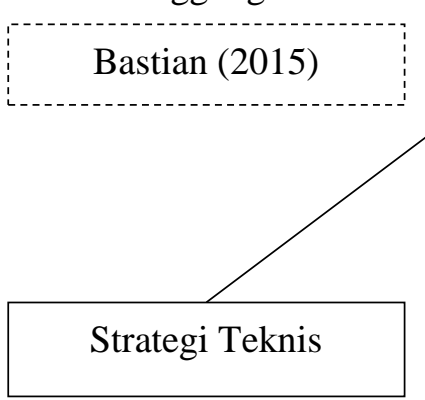

1. Privacy officer

2. Internet of things (IoT)

3. Akses data.

4. ketepatan waktu pelaporan

5. Pengendalian data realtime ACFE (2018)

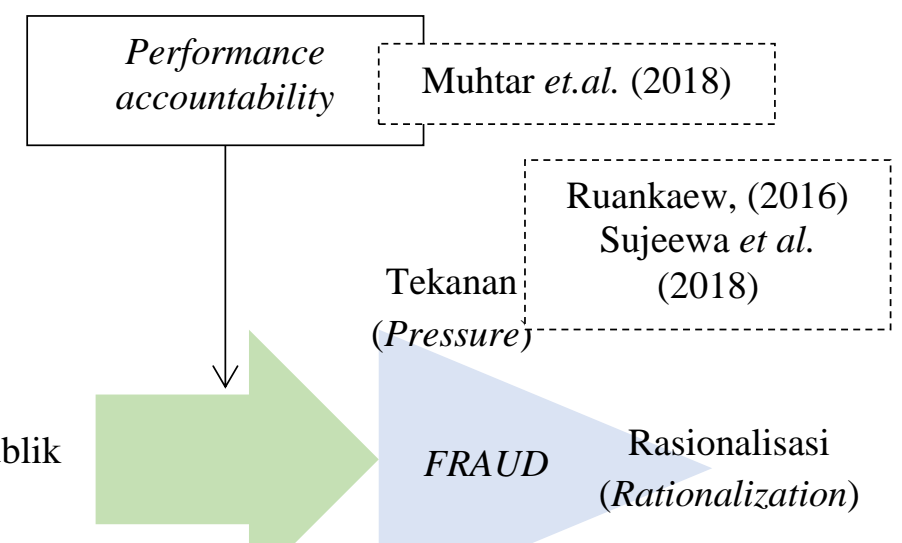

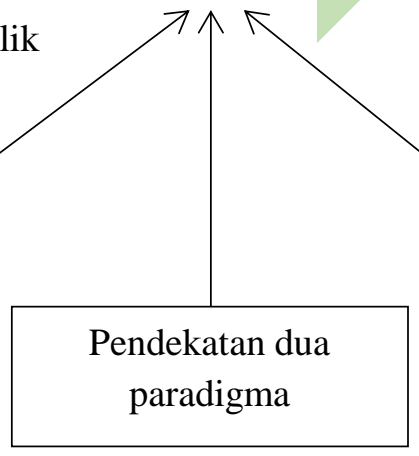

1. Pendekatan budaya

2. Pengendalian internal (internal dan external auditing, fraud examination, forensic accounting
Kesempatan

(Opportunity)
Strategi Preventif

Sistem deteksi Fraud

1. machine learning algorithms

2. Data mining

3. Meta-learning

Donning et.al. (2019)

\section{Gambar 4 Model Penerapan Akuntansi Sektor Publik di Era Digital}




\section{PENUTUP}

Simpulan penelitian adalah yang pertama karakteristik fraud pada sektor publik yang terjadi di era digital antara lain berupa pemanfaatan miskonsepsi mengenai peranan teknologi digital terhadap pelaksanaan tugas akuntan publik, pendayagunaan teknologi digital untuk mengoptimalkan kesempatan untuk melakukan fraud, memanfaatkan permasalahan dalam human error dan kurangnya pengetahuan dalam pemanfaatan teknologi digital, menggunakan produk teknologi digital, seperti cryptocurrency, untuk melaksanakan fraud. Selanjutnya penerapan Akuntansi Sektor Publik dapat mencegah terjadinya fraud pada sektor publik di era digital jika dilaksanakan dengan mempertimbangkan faktor yang mempengaruhi fraud, seperti performance accountability, serta diiringi dengan penerapan metode pencegahan fraud yang meliputi strategi teknis, pendekatan dua paradigma, dan strategi preventif. Strategi teknis mencakup upaya pencegahan fraud melalui pemanfaatan jasa privacy officer, akses loT, mengelola akses data, menetapkan pelaporan yang tepat waktu, dan pengendalian data secara real time. Pendekatan dua paradigma berorientasi untuk menciptakan kultur anti fraud dan menghilangkan kesempatan terjadinya fraud melalui penerapan pengendalian internal. Strategi preventif berupa pengembangan sistem deteksi fraud yang dijalankan dengan metode machine algortithms, data mining, dan meta learning.

Temuan penelitian ini dapat dikembangkan lebih lanjut dengan cara menguji pengaruh dari penerapan Akuntansi Sektor Publik terhadap fraud dengan menggunakan faktor strategi teknis, strategi preventif, pendekatan dua paradigma, dan performance accountability sebagai variabel moderator. Analisis dapat dilakukan menggunakan metode kuantitatif dengan data primer untuk mendapatkan temuan statistik yang akurat. Adapun objek penelitian dapat dipilih salah satu sektor publik yang rentan terhadap fraud sesuai dengan datadata riil yang dapat dikumpulkan oleh peneliti.

\section{REFERENCES:}

Abri, A. F., Arumugam, D., \& Balasingam, S. 2019. Impact of the Corporate Governance on the Financial Statement Fraud: A Study Focused on Companies in Tanzania. International Journal of Recent Technology and Engineering, 8(58), 336-341.

Akay, E. M., Poputra, A. T., \& Kalalo, M. Y. B. 2016. Analisis Aspek Keperilakuan Terhadap Penerapan Sistem Akuntansi Persediaan Pada PT. Surya Wenang Indah Manado. Jurnal Riset Ekonomi, Manajemen, Bisnis Dan Akuntansi, 4(1), 688-697.

Aksa, A. F. 2018. Pencegahan dan Deteksi Kasus Korupsi pada Sektor Publik dengan Fraud Triangle. Jurnal Ekonomi, Bisnis, Dan Akuntansi (JEBA), 20(4), 1-17.

Antarwiyati, P., \& Purnomo, R. E. 2017. Motivasi melakukan fraud dan faktor-faktor yang mempengaruhinya. Jurnal Akuntansi \& Auditing Indonesia, 12(2), 157-166.

Association of Certified Fraud Examiners (ACFE) Indonesia Chapter. 2017. Survai Fraud Indonesia 2016. In Auditor Essentials. Jakarta.

Association of Certified Fraud Examiners (ACFE) Indonesia Chapter. 2018, August). Sewindu ACFE Indonesia. Majalah ACFE Indonesia - Investigate.

Bastian, I. 2015. Lingkup Akuntansi Sektor Publik. In Akuntansi Sektor Publik. Jakarta: Erlangga. 
Bungin, B. 2017. Metodologi Penelitian Kuantitatif. Jakarta: PT Fajar Interpretama Mandiri.

Cahyadi, I. F. 2019. Peranan Sistem Informasi Akuntansi dan Tantangan Profesi Akuntan di Era Revolusi Industri 4.0 (Sebuah Studi Fenomenologi). AKTSAR: Jurnal Akuntansi Syariah, 2(1), 69.

CNBC Editorial. 2018. Cryptocurrency Dibahas dalam Konferensi Anti-Fraud 2018. Retrieved January 10, 2020 , from CNBC Indonesia website: https://www.cnbcindonesia.com/news/20180719084159-424288/cryptocurrency-dibahas-dalam-konferensi-anti-fraud-2018

Creswell, J. W. 2014. Research Design: Quantitative And Qualitative Approach. London: Sage Publishing.

Donning, H., Erikkson, M., Martikainen, M., \& Lehner, O. M. (2019). Prevention and Detection for Risk and Fraud in the Digital Age - the Current Situation. ACRN Oxford Journal of Finance and Risk Perspectives, 8, 86-97.

Enyi, P. 2019. Relational Trend Analysis: A Simple and Effective Way To Detect Financial Statements Fraud. International Journal of Scientific and Research Publications (IJSRP), 9(2), p8669.

Eyo Bassey, B. 2018. Effect of forensic accounting on the management of fraud in microfinance institutions in cross river state. IOSR Journal of Economics and Finance, 9(4), 79-89.

Free, C. 2015. Looking Through the Fraud Triangle: A Review and Call for New Directions. SSRN Electronic Journal, (January 2015).

Hadi, R. 2018. Ini Bentuk Kecurangan Dan Korupsi Finansial di Era Digitalisasi. Retrieved January 10, 2020, from Bukamata website: https://www.bukamata.co/berita/8506/ini-bentuk-kecurangan-dan-korupsi-finansial-diera-digitalisasi/

Halim, A. 2016. Manajemen Keuangan Sektor Publik. Jakarta: Salemba Empat.

Hantono. 2018. Analisis Pendeteksian Financial Statement Fraud Dengan Pendekatan Model Beneish Pada Perusahaan Bumn. Going Concern : Jurnal Riset Akuntansi, 13(04), 254-269.

Ikatan Akuntan Indonesia. 2016. Standar Akuntansi Keuangan Revisi. Jakarta.

Kementrian Riset dan Teknologi Republik Indonesia. (2018). Menristekdikti: Profesi Akuntan Harus Beradaptasi Dengan Revolusi Industri 4.0. Retrieved January 10, 2020, from Siaran Pers Kemenristekdikti website: https://www.ristekbrin.go.id/kabar/menristekdikti-profesi-akuntan-harus-beradaptasi-dengan-revolusiindustri-4-0/

Kementrian Riset dan Teknologi Republik Indonesia. 2019. Sesjen Kemenristekdikti Minta Calon Akuntan Profesional Dibekali Kemampuan Deteksi Tindak 'Fraud' dan Korupsi di Era Digital. Retrieved January 10, 2020, from Siaran Pers Kemenristekdikti website: https://www.ristekbrin.go.id/kabar/sesjen-kemenristekdiktiminta-calon-akuntan-profesional-dibekali-kemampuan-deteksi-tindak-fraud-dan-korupsi-di-era-digital/

Komisi Pemberantasan Korupsi Indonesia. 2018. Rekapitulasi Tindak Pidana Korupsi. Retrieved January 10, 2020, from Anti Corruption Clearing House website: https://acch.kpk.go.id/id/statistik/tindak-pidana-korupsi

Kruskopf, S., Lobbas, C., Meinander, H., Söderling, K., Martikainen, M., \& Lehner, O. M. 2019. Digital Accounting : Opportunities, Threats and the Human Factor. Oxford Journal of Finance and Risk Perspectives, 8(Digital Accounting), 1-15.

Kutluk, F. A. 2017. Behavioral Accounting and its Interactions. Accounting and Corporate Reporting - Today and Tomorrow. https://doi.org/10.5772/intechopen.68972

McMahon, R., Pence, D., Bressler, L., \& Bressler, M. S. 2016. New Tactics In Fighting Financial Crimes: Moving Beyond The Fraud Triangle. Journal of Legal, Ethical and Regulatory Issues, 19(1), 16-25.

Muhtar, Sutaryo, \& Sriyanto. 2018. Corruption in Indonesian local government: Study on triangle fraud theory. International Journal of Business and Society, 19(2), 536-552.

Omar, M., Nawawi, A., \& Salin, P. 2016. The Causes, Impact And Prevention Of Employee Fraud - A Case Study Of An Automotive Company. Journal of Financial Crime, 23(4), 1012-1027.

Peprah, W. K. 2018. Predictive Relationships among the Elements of the Fraud Diamond Theory: The Perspective of Accountants. Academic Research in Accounting, Finance, and Management Science, 8(3), 141-148. https://doi.org/10.6007/IJARAFMS/v8-i3/4547

Pertiwi, P. 2018. Cryptocurrency dan Risiko Tindak Kecurangan. Retrieved January 10, 2020, from Integrity Indonesia website: https://www.integrity-indonesia.com/id/blog/2018/03/02/cryptocurrency-dan-risikokecurangan/ 
Putritama, A. 2019. Peluang dan tantangan profesi akuntan di era big data. Jurnal Akuntansi, 7(1), 74-84. https://doi.org/10.24964/ja.v7i1.758

Rini, Y. T. 2019. Mengurai Peta Jalan Akuntansi Era Industri 4.0. Jurnal IImu Manajemen Dan Akuntansi, 7(1), 5868.

Ruankaew, T. 2016. Beyond the Fraud Diamond. International Journal of Business Management \& Economic Research, 7(1), 474-476.

Said, J., Alam, M. M., Karim, Z. A., \& Johari, R. J. 2018. Integrating religiosity into fraud triangle theory: findings on Malaysian police officers. Journal of Criminological Research, Policy and Practice, 4(2), 111-123.

Septarini, D., \& Papilaya, F. 2016. Interaksi Komitmen Organisasi Terhadap Faktor-Faktor Yang Mempengaruhi Kualitas Laporan Keuangan Pemerintah Daerah. Jurnal IImu Ekonomi \& Sosial Unmus, VII(2), 100-116.

Sihombing, E., Erlina, Rujiman, \& Muda, I. 2019. The Effect Of Forensic Accounting, Training, Experience, Work Load And Professional Skeptic On Auditors Ability To Detect Of Fraud. International Journal of Scientific and Technology Research, 8(8), 474-480.

Sujeewa, G. M. M., Yajid, M. S. A., Azam, S. M. F., \& Dharmaratne, I. 2018. the New Fraud Triangle Theory Integrating Ethical Values of Employees. International Journal of Business, Economics and Law, 16(5), 5257. Retrieved from http://ijbel.com/wp-content/uploads/2018/08/ijbel5_216.pdf

Supriyono, R. A. 2018. Akuntansi Keperilakuan. Yogyakarta: Gajah Mada University Press.

Wahyuni, W., \& Budiwitjaksono, G. S. 2017. Fraud Triangle Sebagai Pendeteksi Kecurangan Laporan Keuangan. Jurnal Akuntansi, 21(1), 47.

Zanaria, Y. 2017. Pengaruh Aplikasi Teknologi, accounting reporting Terhadap Pencegahan Fraud dan serta imlplikasinya terhadap reaksi investor. Jurnal Akuisisi, 13(1), 91-100. 
